\title{
The Legacy and Legendary of Ibn Khaldun as a Fore-Runner Scholar in Sociology
}

\author{
Olatunji Abdulganiy $^{1} \&$ Abdulganiy Abdullah Olamilekan ${ }^{2}$ \& Abdulbaki S. $\mathrm{Z}^{3}$
}

\author{
${ }^{1,2,3}$ Department of Sociology, Faculty of Social Sciences University of Ilorin, Ilorin, Nigeria \\ Correspondence: Olatunji Abdulganiy, University of Ilorin, Ilorin, Nigeria. \\ Email: info@olatunjiabdulganiyu.com.ng
}

Received: December 17, $2018 \quad$ Accepted: January 25, $2019 \quad$ Online Published: March 1, 2019

doi: 10.23918/ijsses.v5i3p128

\begin{abstract}
The paper attempts to establish the fact that, though sociology is regarded as purely a Western enterprise but a further examination of some non-western intellectual piece would reveal the opposite. General assessment was made of Ibn-Khaldun ideas in the Muqodimat with the aid of previous scholarly works that have assessed the masterpiece. Further effort was made in the paper to specifically show topical sociological issues raised by Ibn-Khaldun. Effort was made to compare and contrast his scholarly explanations with that of notable western sociologists. This paper shows that Ibn-Khaldun is a prominent classical sociological figure that should be accorded a legendary position and that his masterpiece is a legacy for present and future social engineers. Based on the relevance of Ibn-Khaldun work to the discipline of sociology, modern sociologists should put vested interest in studying Ibn Khaldun as one of the fore runners of the discipline.
\end{abstract}

Keywords: Classical Sociology, Group-Feelings, Civilizations, History, Legacy, Arabs

\section{Introduction}

The core objective of sociology as a distinct academic field of study is to critically peruse, examine and consequently understand and as well interpret the nature and dynamics of social realities with the long run aim of not just understanding the structure of human society but also explain the metaphysical elements that condition the nature of the structure. Consequent upon this orientation, scholars and philosophers from time immemorial have been engaging in critical thinking in a bid to provide formidable explanations about the dynamics of human society. Accordingly, some of these scholars like Aristotle, Plato, and Thomas Hobbes - were obsessed with the political aspects of the society, others like Karl Marx; Adam Smith gave priority to the economic aspects of it. Basically, most of these classical scholars focused specifically on an aspect of the society but sociology wants to see the society from all angles.

The term sociology was formally coined and introduced by August Comte in the $18^{\text {th }}$ century. However, this is not to say that explanations concerning the way the society works have not been provided prior to this time. Before the arrival of Comte, scholars like Aristotle, Plato, Socrates and the likes had provided series of explanations about the workings of the social system. However, it would be wrong to assume 
that intellectual explanation about the working of human society is exclusively a western phenomenon, Ritzer (2011, p. 5) remarked thus "there is a tendency to think of sociology as exclusively a comparatively modern, Western phenomenon. In fact, however, scholars were developing sociological ideas and theories long ago and in other parts of the world".

One notable example of such scholar with non-western background is a Tunisian scholar of great dexterity and prowess, Abd Ar Rahman bin Muhammed ibn Khaldun who as far as the Fourteenth century has provided a systematic formidable intellectual explanations on the dynamics of the workings of the society. A closer examination of Ibn Khaldun's explanation on human social organization would reveal the fact that such explanations are rich enough to compete favourably and be conveniently compared to the positions later offered by notable Western sociological figures such as August Comte, Emile Durkheim, Herbert Spencer, Karl Marx, Max Weber and others.

However, despite the richness and quality of Ibn Khaldun's explanations on the dynamics of the workings of human society, little is he acknowledged as a classical sociological legend and lesser is the legacy of his works given such sociological prominence. Different reasons are alluded as the cause of this. To some scholars such as Ogunbameru (2015), the reason might be as a result of the fact that he is not from a Western society, Ogunbameru (2015) stated that; a general review of contemporary histories of social thought and social theory will reveal that very little attention is given to non-western precursors of sociology or non-western social thinkers. In the candid view of these authors, the reason might be as result of the fact that, like many historical works of his time, his sociological explanations of human society is oriented towards historical analysis of Arabian society unlike the works of August Comte, Karl Marx, Marx Weber and so on who use historical analysis as empirical data to justify their explanations on the working of human society.

For instance, Karl Marx uses the course of history to justify the assertion that the history of all hitherto existing society is the history of class struggle. Similarly, Max Weber uses history as the raw data to justify the fact that social value (the protestant ethics) has significant effect on the development of Capitalism in the West. In addition to the above possibilities, the view of this paper is that though Ibn Khaldun's explanation has sociological relevance but little has modern sociologists put vested interest in bringing out the sociological elements in his work. Thus, this paper is an attempt to cover this gap. In other words, this manuscript is an attempt to make complementary explanations of Ibn-Khaldun's work using sociological lenses in order to show his legendries and legacies as a sociologist. This is necessary not just to bring out the richness of Ibn Khaldun intellectual stances (as a contributor to various disciplines such as philosophy, history, economics, jurisprudence and indeed sociology) but also to show the sociological bases of his explanations.

\section{Who is Ibn Khaldun?}

Every human being irrespective of his/her social status must have a specific life-course, that is a particular feature of his/her life that will differentiate the history of the fellow from any other. In many instances, a historical account of people is usually done by people after their demise, however, in the case of Ibn Khaldun, the reverse is the case, Ibn Khaldun himself left a comprehensive autobiography of himself before he died. One factor that made the account more unique was the fact that the autobiography was written by him at the tail end of his life (Rosenthal, 1967). As a social historian, he 
understands the 'how' and 'what' of a biography and he tried as much in that regard to do justice to writing the biography of himself. As a result of this, discourse on the biography of Ibn Khaldun is never a difficult task. His effort of writing an auto-biography of himself has saved commentators of his life the time of jostling around to gather such information and also lower the rate at which there will be discrepancy and incongruity between biographers on Ibn Khaldun's life.

In his autobiography tagged: At-ta'reefu bi-ibni Khaldun wa rihlatuhu garban wa sharqan (Introducing Ibn Khaldun and his journey North and West) written in the year 1405. He revealed that his progenitor was referred to as Khaldun. According to Hozien (undated), Khaldun belonged to a clan of South Arabian origin; he was believed to have immigrated to Spain in the eighth century. According to Ibn Khaldun in his autobiography, cited by Rosenthal (up cited); only ten generations separated him from the founder of his family (Khaldun). His ancestors were known to be political gladiators. Ibn Khaldun was born in Tunis on Ramadan 732 in the Hijrah calendar which equalises May 27, 1332 (Walter, 1967) His real name was Abdu -r- Rahman. He was prominently and popularly known as Ibn Khaldun (son of Khaldun). His ethnic denomination was al-Hadrami rooted in Hadramawt, the ancestral home of his clan in South Arabia (Mahadi, 1957).

Ibn Khaldun was given several scholarly titles during his lifetime; he got married before he arrived Fez. His wife was a daughter of Muhammad bn. al-Hakim. Ibn Khaldun was deeply devoted to his family, but was frequently separated from them for long periods of time due to his roaming attitude. Ibn Khaldun was very inquisitive and as such has flair for knowledge acquisition. Ibn Khaldun was tutored by his own father and also learned from number of scholars. It is noteworthy that, Ibn Khaldun learnt many of the disciplines at his tender age. Ibn Khaldun was an erudite renowned scholar; this is evident not just in the intellectual quality of the Masterpiece (Muqoddimat) but also in several intellectual positions held by him in his lifetime. Roshni (2012) noted that Ibn khaldun spent his last 24 years in the city of Cairo, Egypt where he was made the Chief Judge and Lecturer at the Al-Azhar University, Cairo.

According to Ritzer (2011), Ibn Khaldun died in the year 1406 AD at 73 years of age. However, before his death he had produced a corpus of scholarly ideas that have background in various academic fields such as: Astronomy, Literature, Politics, Economics, Jurisprudence, Geography, History and Sociology (Ogunbameru, 2015). To this extent, Ibn Khaldun could be referred to as a man of encyclopaedic knowledge and an intellectual to the core. Ritzer (2011) specifically remarked that the writings of Ibn Khaldun had many ideas in common with contemporary sociology. In the word of Gellner (1975) cited in Kathy (2005), Ibn Khaldun was a positivist who was more empirical than Durkheim.

\section{3. "Mukodima"}

\subsection{What about His 'Mukodima'?}

Although records show that Ibn Khaldun wrote lots of academic manuscripts in forms of pamphlets, lecture notes and books, very prominent among these pieces is the Muqaddima. The Muqaddima is referred to as the masterpiece of his works due to the qualitative intellectual elements contained in it. Literally, Muqaddima means introduction or preface. According to the Wikipedia, Muqaddimah could be translated to 'Prolegomena' or 'Introduction' and was written in the year 1377 C.E. Thus, it is interesting to note that Muqaddima is a preface or an introduction to a book written by Ibn Khaldun 
titled: "Kitab al-ibar fi akhbar al-Arab wa-l-'ajam wa-l-Barbar meaning 'Writings on foresights into the history of the Arabs and the Barbers'. The Muqaddimah was originally written by Ibn Khaldun in the Arabic language, though; it had been translated to English language by numerous translators. The Muqaddimah has various sections concerned with different subject matters such as sociology, history, geography, politics, economics and even psychology.

In the preface of the book, Ibn Khaldun tried as much as possible to bring out the importance and relevance of his historical account of the human societies he wanted to analyse. Through those historical accounts he tried as much as possible to bring out the fact that what he is observing through historical accounts of the societies in point is similar to what could be obtainable in virtually every human social setting. Like many naturalists/objectivists, he is of the view that there are fundamental natural principles governing the existence of human society (Caksu, 2007).

In his effort to justify his assertion, he picked on several aspects of human socio-physical existence viza-viz their geographical environment, political-economy and their general social arrangements. In Geography, he described the earth and carved a map of the world; in politics, he discussed the inevitability of leadership to maintain orderliness and also discussed economics as an important inevitable social institution. While analyzing the social organization of the Arabs and Berbers; he dwelled on the dynamics and primacy of social integration; social change and the essentiality of social life or group living (Rabi, 1967). Although, Ibn Khaldun contributed to various areas of human endeavours, the major focus of this present manuscript is to make concerted effort to bring out the sociological elements in this various areas of studies discussed in the masterpiece.

\subsection{Sociology in the Muqoddima}

Ibn Khaldun has been spotted to have contributed enormously to human endeavours viz-a-viz geography, politics, history, sociology, economics and jurisprudence. However, because many of his discussions on these subjects are targeted towards bringing the fundamental principles (causes) governing the formation and operation of human society (effects), many of these works are consequentially sociological. His submissions to these realms of knowledge cannot just be overemphasised. For instance, on politics, Ibn khaldun argued that man by nature is political; he submitted that men must be governed and ruled by a single person in order to avert conflict between them. He noted that, some people may want to override others because they wield power but if a leader who will draft laws guiding the society is in existence, the situation in the society will be brought to normalcy and nobody will trespass (Rabi, 1967).

Carefully studying the submission of Ibn khaldun, it could be likened to that of Hobbes' Leviathan, where he supported the idea that the single most powerful individual (Leviathan) should rule the society to eliminate the state of nature where man was like a wolf to his neighbours. In his Muqaddimah, Ibn Khaldun stated that the ruler should not necessarily be selected on the basis of religious affiliation. He advocated a leader who is influential and can always control his people successfully. To prove this assertion empirically, he took time to analyse the Arab caliphate system to show the interplay of power amongst the people. A closer look at the above submissions would reveal the fact that Ibn Khaldun's work in the Mukoddimo is deeply rooted in political sociology. 
As regards his contributions to geography, Ibn khaldun submitted that the earth is spherical, surrounded by water. He noted that there are some parts of earth that are free from water; these parts according to him are suitable for social living. Ibn khaldun sketched out the map of the world. In his remark, he made some observations that are relevant for ecological sociology; he noted that geographical topography of an environment to a great extent will determine a lot about their social behaviour and their socio-cultural existence vis-a-vis occupation, dressing pattern, political-economic activities and the dynamics of social change in the society. This observation could be likened to the views of the Chicago school on the influence of environmental factors on socio-cultural and behavioural dynamics of the people in the society. Specifically, he noted that, the northern quarter of the earth has more civilisations than the southern quarter due to the differences in their geographical settings. More specifically, it could be right to say that, Ibn Khaldun level of analysis in the Muqaddima tends more towards sociology than any other disciplines, the quality of sociology in Ibn Khaldun's work makes some observers to conclude that Ibn Khaldun could be referred to as one of the classical sociologists. Ogunbameru (2015, p.30) in this respect noted thus:

His (Ibn Khaldun) original ideas and thoughts are presented in his famous Muqaddimah; conceived as an introduction to his universal history, it is considered today to be one of the primary works in the history of human social thought in general and one of six most important monographs in sociology in particular.

The above notwithstanding, it is the conception of these authors that enough sociological effort is yet to be devoted to bringing out the sociological elements in Ibn Khaldun's work. It is therefore imperative to show how his work could be rooted in sociology by not just spelling out these elements but by also juxtaposing it with that of classical and modern sociologists. Generally, Ibn Khaldun had contributed largely to several areas of sociology ranging from social organisation; division of labour; social control; socialisation, group analysis and so on. In order to further justify this assertion, these different areas of sociology contributed to by Ibn Khaldun would be further expatiated.

\subsubsection{Social Organisation}

Organization is one of the basic features of human animal and the very element that conditioned social life, it could be right to say that social life and social organization are inseparable due to the symbiotic relationship between them, thus as social life provide the basis for social organization, social organization in turn enhances social life. This could be adduced as the reason why sociology is sometime described as the study of social organization (Shaka-Rao, 2006). Thus, it is an undisputable fact that the study of social organization is one of the central focuses of sociology and that any individual that put vested interest in critically examining the dynamics of social organization could be referred to as a sociologist. Ibn Khaldun contributed immensely to this aspect of sociology where he acknowledged the fact that social organisation is a basic requirement for social life and that its existence in human society is inevitable. He proved its inevitability with the fact that human beings are dependent upon one another; no one is capable of doing everything, there is a need for a people to be socially organised, he emphasised the sayings of the philosophers that, human being is by nature a social animal. As soon as several human beings begin to cooperate with each other and to form some kind of social organization, 'umran' 'social life or social living' results. Umran (social life) is one of the key sociological terms in 
Ibn Khaldun's work; the term is used to designate any settlement above the level of individual savagery. Thus, 'umran' implied 'society' in the context in which it is used by Ibn Khaldun and he frequently uses the word in this sense. Wherever and whenever people are cooperating with each other, no matter how limited the scale, there is 'social life' and by consequence, there is social organization and when the number of these people increases, a larger and better society results. The growth in numbers, with a corresponding progress in organization finally culminates in the highest form of social life man is able to achieve; it declines from this peak when the number of cooperating people decreases.

Thus, the origin of man's social organization could be located in the fact that all human activities are undertaken to enable the individual to preserve his life and to secure his livelihood through interactions and relationship with other members of the community. To that end, each man has to contribute his labor, which is his only basic capital, to satisfy the fundamental needs of his group. When there is a large number of human being, a large amount of labor, even an excess supply of it, becomes available (the source of surplus labour). Thus, certain amount of labor may then be channeled into the production of things and the provision of services that are basically and luxuriously necessary for continual living. Ibn Khaldun's conceptions on large amount of labour and channeling labour to different areas of production could be likened to the economists' conception of surplus labour and division of labour. He remarked that:

God created and fashioned man in a form that he (man) can live and subsists only with the help of food. He guided man to a natural desire for food and instilled in him the power that enables him to obtain it. However, the power of the individual human being is not sufficient for him to obtain (the food) he needs, and does not provide him with as much varieties of food as he requires to live. Even if he assume an absolute minimum of food, that is, food enough for one day, that amount of food could be obtained only after much preparation such as grinding, kneading and baking. Each of these three operations requires utensils and tools that can be provided only with the help of several crafts, such as the crafts of the blacksmith, the carpenter and the potter (Cited in Rosenthal, 1967, p.87)

He noted further:

Assuming that a man could eat unprepared grain, an even greater number of operations would be necessary in order to obtain the grain: sowing and reaping, and threshing to separate it from the husks. Each of these operations requires a number of tools and many more crafts than those earlier mentioned. It is beyond the power of one man alone to do all that, or (even) part of it, by himself. Thus, he cannot do without a combination of many powers from among his fellow beings, if he is to obtain food for himself and for them... (Rosenthal, 1967, p. 87).

Making inference from the analysis given above, Ibn Khaldun remarked that it is only through social interaction, social relationship and social organization that the needs of individuals and generality of 
people in the society can be met. Justifying the need for social organization further, Ibn-Khalidun used the primacy of security to expatiate this further. Aside, food, another basic necessity of life is security; going by Abraham Maslow's theory of needs, security needs is one of the utmost needs of human animal (Maslow, 1949). In fact, every animal be it lower or higher animals are programmed with survival/security instincts such that any animal without such features is bound to extinct. Thus, it could be said that the human animal has been able to exist and persist to this extent basically as a result of his ability to protect and secure itself against various security threats such as wild animals and harsh weather conditions. In the view of Ibn Khaldun, one very important element needed to achieve this, is existence of social organization. Accordingly, the extent at which human animal is able to organize themselves socially; the extent they are likely to be able to secure and protect themselves from various security threats and achieve various conditions of good social living. Thus, each individual needs the help of his fellow beings for his defence, security and overall social existence. This, he buttressed by the following analysis:

When God fashioned the natures of all living beings and divided the various powers among them, many dumb animals were given stronger power than man. The power of a horse, for instance, is much greater than the power of man, and so is the power of a donkey or an ox. The power of a lion or an elephant is many times greater than the power of (man) and aggressiveness is natural in living beings, (thus the tendency of preying on one another). Therefore, God gave each of them a special limb for defense against aggression. To man, instead, He gave the ability to think, and the hand. With the help of the ability to think, the hand is able to prepare the ground for the crafts. The crafts, in turn, procure for man the instruments that serve him instead of limbs, which other animals possess for their defense. Lances, for instance, take the place of horns for goring, swords take the place of claws to inflict wounds, shields take the place of thick skins, and so on. The power of one individual human being cannot withstand the power of any one dumb or predatory animals. Man is generally unable to defend himself against them by himself. Nor is his (unaided) power sufficient to make use of the existing instruments of defense, because there are so many of them and they require so many crafts and (additional) things. It is absolutely necessary for man to have the co-operation of his fellow men. As long as there is no such co-operation, he cannot obtain basic life necessities such as food, clothing, protection and nourishment, and life cannot materialise for him because God fashioned him so that he must have food if he is to live and must also develop weapons to defend himself to avoid falling prey to animals. When, however, mutual co-operation exists, man obtains food for his nourishment and weapons for his defense ... (cited in Rosenthal, 1967, p.86)

What could be inferred from the foregoing is that Ibn Khaldun gave an empirical account of the necessity of social organization for the course of providing food, shelter, defence and other necessities and luxuries that will make life convenient and worthwhile for the populace. Man corporates and collaborates with other human beings in a given society; such cooperation and inter-dependence between and among the people in the society amounts to social life, division of labour and improved social organization. Comparatively, it could be seen from the analysis thus far that Ibn Khaldun proposed a concept similar to Durkheim's division of labour, this is because he submitted that, since man alone cannot provide for himself, there is a need to collaborate and as well divide the labour amongst 
themselves, whereby an individual will get the food, another will cook it, another will provide the equipment to prepare it and another will also provide weapons for self defence against wild animals. In essence, social organization is a sin-qua-non as humans need themselves not just to live a comfortable life but more importantly to preserve human live and protect it against predatory animals and harsh environment. A closer examination of the above analysis would reveal the fact that Ibn-Khaldun offered a rich intellectual account of the primacy and dynamics of social organization in a typical human society.

\subsubsection{Leadership as a Mechanism of Social Control}

In a bid to further buttress the principles that condition the working of human social system and by extension their course of history, Ibn Khaldun explained, that for a society to be peaceful and orderly, there is a need for a quality leadership. Human beings, according to Ibn Khaldun are aggressive and inherently violent; such nature according to him is the cause of incessant social struggles, unrests, conflict and wars that dominated human history. This he put technically as 'war of all against all', which is generally inimical to desired social needs of peace and tranquillity living desired by all and sundry. This position could be likened to that of Karl Marx that propounded that 'the history of all hitherto existing society is the history of class struggle'.

Ibn Khaldun as a 'functionalist' who believes in the primacy of social order, he presumed that, there was a need to have an individual, whom, powers will be submitted to and as well given the authority to rule. This, in every way is similar to the grand assumption of Thomas Hobbes, who was perturbed by the state of nature, where there was war of all against all. Hobbes, in a bid to eliminate the war of all against all proposed the existence of a 'supreme or executive leadership' (Leviathan). Hobbes noted that, the Leviathan should be accorded the power to rule and maintain orderliness by legislating and as well enforcing the legislation in order to maintain social order. Ibn Khaldun submitted that, the leader should not necessarily be religiously inclined. What matters most to him was the ability of the leader to wield power, command respect and gain influence. He remarked thus:

When mankind has achieved social organization, as we have stated, and when civilization in the world has thus become a fact, people need someone to exercise a restraining influence and keep them apart, for aggressiveness and injustice are in the animal nature of man. The weapons made for the defense of human beings against the aggressiveness of dumb animals do not suffice against the aggressiveness of man to man, because all of them possess those weapons. Thus, something else is needed for defense against the aggressiveness of human beings toward each other. It could not come from outside, because all the other animals fell short of human perceptions and inspirations. The person who exercises a restraining influence, therefore, must be one of themselves. He must dominate them and have power and authority over them, so that no one of them will be able to attack another (Cited in Rosenthal, 1967, p. 88). 
Ibn Khaldun mentioned that such example of influential leadership also exists among certain dumb animals, such as the bees and the locusts. One discerns among them the existence of authority and obedience to a leader. They follow the one of them who is distinguished as their leader by some natural physical and metaphysical characteristics. In a very closer analysis of Ibn Khaldun's stance on leadership and the maintenance of social organization, his arguments could be likened to that of many assumptions in political sociology theories that assumed that leadership is traditional to human social organization. Specifically, such tone of understanding could be observed in the works of Hobbes, Aristotle, Machiavelli, Emile Durkheim, Max Weber and so on. For instance, max Weber spoke of authority as power backed by legitimacy and that without authority, leadership positions might not yield the desired result.

\subsubsection{Classification of Human Society}

Without mincing word, sociology as an academic discipline has its long run aim at discovering the basic structure of human society (Broom \& Selznick, 1968). In this regard, sociologists have always tried to give classified explanation relating to the dynamics and nature of human society. Classifying societal typologies is so keen to the sociological enterprise such that any academic effort that put vested interest in classification of society is usually tagged a sociological piece. At different levels, different sociologists at different points in time have classified human societies using the elephantine approach. For instance, August Comte classified it in terms of development of human reasoning to metaphysical, traditional and positivist; Emile Durkheim classified it in terms of the nature of social solidarity in human society to mechanical/organic societies, Ferdinand Tonnies classified it as comprising of Gemeinschaft and Gessellchaft. Thus, it is actually impressive that same classificatory model given by erudite sociologists in the late $18^{\text {th }}$ to early $19^{\text {th }}$ centuries has been offered by Ibn Khaldun over three centuries earlier.

Having studied the history and nature of the social system, Ibn Khaldun classified human society into two general types probably based on the population and some other socio-cultural factors that characterize living among the inhabitants of the two opposing societies. He identified the Bedouin and Sedentary Society; the Bedouin society according to Ibn Khaldun is a simple society with simpler population and less complex socio-cultural cum economic characteristics, it is a 'folk' society, a more or less a rural ethno-centric society. Its occupants do not pursue beyond their bare daily needs. They are predominantly farmers, herdsmen and pastoralists. This Bedouin society he described in Arabic word as the (Umran ul Badawi) (rural/traditional life). He also submitted that the Bedouins are more likely to be better in character and morally upright compared to their counterparts living in the other societal type. He also pinpointed that the Bedouins always possessed a higher dose of group feeling (asabiyah) due to their ethnocentric orientations. From this analysis, one could vividly realize that Ibn-Khaldun's general conception of the Bedouin society is similar to Durkheim's Mechanical Solidarity, Weber's Traditional Society, Tonnies' Gemeinschaft and Howard's Sacred Society. All these terminologies as used distinctively by each scholar presuppose a rural society characterised by less complex social arrangement. Durkheim in his explanations on mechanical solidarity noted that people living in rural society possessed an integration typology, which could be likened to the working of a mechanical object where no part of the system can operate so conveniently without the other - so connected and socially bonded such that one cannot do without the other. 
Ibn Khaldun contrasted the Bedouin society with the sedentary society. In the word of Ibn Khaldun, it is tagged (Umran ul Hadari) (urban/modern living). Sedentary people means the inhabitants of cities and countries, some of whom adopt the crafts as their way of making a living, while others adopt commerce. He noted that those living in the Sedentary Society generally possessed a sedentary culture, always live a luxurious life, they request more than bare necessities, they possessed a hyper orientation towards living; they live life such that even if they would need 'the interdependence', such would be at a minimal level and they rarely possess group feeling as individualism is usually the order of the day. Hence, they go through all means whether legal or illegal to satiate their needs. This made Ibn Khaldun asserts that they are most likely to be 'morally bankrupt' and 'develop bad character'. In a sharp comparism, the sedentary society could be likened to Durkheim's conceptions of Organic Solidarity, Weber's position on traditional Society, Tonnies statements on Gesellschaft, Howard Becker's conclusion on Secular Society.

In addition to the above, it is intellectually stimulating to observe that Ibn Khaldun's view on characteristics of urban life style corroborates the view of Robert Park in his study tagged 'Street Corner Societies' where he submitted that the urban life is usually violent and aggressive. It is also in tandem with the view of Howard Becker on the classification of the society as sacred and secular. In this sense, analysis of these scholars on classification of human society could be traceable to the work of Ibn Khaldun.

What could be inferred from the discussion this far is that Ibn-Khaldun tried so much to give an empirical analysis on the fact that human societies are not of the same in terms of their socio-cultural make-up and that understanding the dynamics of the typologies would go a long way in understanding the dynamics of the workings of human society. Just like many scholars after him, Ibn-Khaldun used the course of history as raw data to drive home his points on the subject matter of typologies of human society. Based on the high level of similarities that could be drawn from his explanations and that of later sociological scholars, one would not doubt the fact that Ibn Khaldun's work is deeply a sociological masterpiece.

\subsubsection{Human Behavioural Dispositions}

Behaviourism is a core area of sociology that has gained attention of sociologists since the neo-classical period of the discipline (Ritzer, 2011). One of the factors that led to the development of behaviourist school of thought in the sociology is the realization on the part of scholars that society is a 'hand-made' of the people, (socially constructed) that is, that the society is created through human actions and inactions (behaviour). According to this school of thought, if human being in the society seizes to behave in a particular way or the other, then the society would seize to exist. As cited in Rosenthal (1967), in Ibn Khaldun's view of history, the whole world and everything in it depends upon man, there is no room for an abstract concept of a state. A state exists only in so far as it is occupied by behaving human beings. In this regard, examining and analysing the dynamics of human behaviour has been another interesting focus of the discipline of sociology. To further show the sociological depth in Ibn Khaldun's work, this chapter has tried to show the behaviourist stunts in the Muqoddimat.

Khaldun's notion on the dynamics of human behaviour could be inferred as he tries to explain the differences in the two types of societies earlier discussed in this write-up. In the bid to further explain 
the causes of the differences in the behavioural dispositions of the Sedentarists compared to the Bedouins, Ibn Khaldun explained that the differentials in socio-environmental characteristics of the two societies condition the differentials in their behavioural dynamics. In this instance, Ibn Khaldun proposed a concept similar to John Locke's 'Tabularaza'. He noted that the soul in the stage of birth is as white as snow and that whether the soul becomes corrupt or not is dependent on the conditions of the environment and the socio-cultural operations of the society the child finds his/her self. He stated thus:

The reason for it is that the soul in its first natural state of creation is ready to accept whatever good or evil may arrive and leave an imprint upon it. To this degree, the soul is first affected by one of the two qualities, it moves away from the other and finds it difficult to acquire it. When customs proper to goodness have been first to enter the soul of a good person and his (soul) has thus acquired the habit of (goodness, that person) moves away from evil and finds it difficult to do anything evil (Cited in Rosenthal, 1957, p. 165).

His explanations on how socio-environmental factors shaped people's behaviour could be spotted in his submission in the Muqaddimah as thus:

It should be known that differences of condition among people are the result of the different ways in which they make their living. Social organization enables them to cooperate toward that end and to start with the simple necessities of life, before they get to conveniences and luxuries. Some people adopt agriculture, the cultivation of vegetables and grains, (as their way of making a living). Others adopt animal husbandry, the use of sheep, cattle, goats, bees, and silkworms, for breeding and for their products. Those who live by agriculture or animal husbandry cannot avoid the call of the desert, because it alone offers the wide fields, acres, pastures for animals, and other things that the settled areas do not offer. It is therefore necessary for them to restrict themselves to the desert. Their social organization and co-operation for the needs of life and civilization, such as food, shelter, and warmth, do not take them beyond the bare subsistence level, because of their inability (to provide) for anything beyond those (things). Subsequent improvement of their conditions and acquisition of more wealth and comfort than they need, cause them to rest and take it easy. Then, they co-operate for things beyond the (bare) necessities. They use more food and clothes, and take pride in them. They build large houses, and lay out towns and cities for protection. This is followed by an increase in comfort and ease, which leads to formation of the most developed luxury customs. They take the greatest pride in the preparation of food and a fine cuisine, in the use of varied splendid clothes of silk and brocade and other (fine materials), in the construction of ever higher buildings and towers, in elaborate furnishings for the buildings, and the most intensive cultivation of crafts in actuality. They build castles and mansions, provide them with running water, build their towers higher and higher, and compete in furnishing them (most elaborately). They differ in the quality of the clothes, the beds, the vessels, and the utensils they employ for their purposes... (cited in Rosenthal, 1967, pp. 161-162) 
Although, the analysis above focus on lifestyle patterns of people in two contrasting social system, but a closer examination of the analysis would further reveal the fact that human behavioural dispositions are generally caused by some metaphysical factors which could actually be located in the social environments and the socio-cultural dynamics of the people in a given social arrangement or society. This position is actually one of the core propositions of the behaviourist school in the social sciences generally and sociology especially. For an example, differential association theory proposed that the level of association of an individual with a particular set of culture would determine his level of involvement in either conformity or deviance. This further buttressed the extent at which Ibn Khaldun's analysis would have given the background on which many later sociological works have built upon.

\subsubsection{Group Feeling (Al-Asabiyyah)}

In furtherance of Ibn Khaldun's classifications of human society, he like notable sociologists after him spent whole lots of time to bring out the primacy of social integration in determining the state, nature and general conditions of a specific human society. In order to drive home his point on social integration, he used the examples of a typical Bedouins and the sedentary societies. Ibn khaldun is of the view that social solidarity is deeply rooted in the psychology of the people and one of the major elements conditioning their social conditions. A term he described as Assabiyah 'group feeling' or 'social bond'. He observed that level of doses of the Assabiyah in a group of people would determine the level of social bond, social solidarity or social integration among them. Ibn Khaldun conceived of the term as been associated with the related words 'isdbah and 'usbah, both meaning "group" in a more strict sociological sense, it could be directly translated to imply 'ethnocentrism'. Naturally, the group with which a human being feels most closely connected is primarily that of his ethnic relatives, the people with whom he shares a common descent. According to Rosenthal (1967), as a feeling and a state of mind; the 'asabiyah' can also be shared by people not related to each other by blood ties but by long and close contact as members of a group.

According to Rosenthal (1967), preponderance of 'asabiyah' 'in-group feelings' renders one group superior to others; it also determines leadership within a given group. The leading or ruling element within one or more groups will be that person or, more frequently, that family, the importance and ramifications of whose blood relationships give them the strongest and most natural claim to control of the available 'asabiyahs'. And no group can retain its predominance, nor any leader his dominant position in the group, when their former 'asabiyah' is no longer there to support them. The leader who controls an 'asabiyah' of sufficient strength and importance may succeed in founding a dynasty and in winning mulk, 'royal authority' for himself and his family. He noticed that the Bedouins have higher dose of group feelings and hence the reason for such high level of social bonds between them, this elements according to him invigorates the members of the Bedouin Society such that they experience low level of social conflict and misunderstanding and also perform the function of being able to protect them from external aggression. Rosenthal $(1967$, p.165) puts it as "the Bedouins are well protected on the basis of their social bond". Conversely, in the Sedentary setting where there is no strong group feeling, they easily fall prey to internal wrangling and external attacks. Generally, Ibn Khaldun's analysis of the importance of solidarity in group life has brought out further the sociology in Ibn Khaldun's work. 


\subsubsection{The Cyclical Theory}

Essentially, one of the core areas of sociology since the classical period is 'social change' denoting from the works of the forerunners and contemporary sociologists, it would be unequivocally said that sociology could be regarded as the 'study of social change'. As a result, explaining the dynamics of social change in human society has been one of the landmark contributions of sociology to the understanding human social world. To this extent, several theoretical orientations have been built by sociologists over the years; one of such theoretical positions is the cyclical perspective of social change.

It is worthy of note that one area of analysing human society that Ibn-Khalidun contributed to in his Mukoddimo is in this area. Ibn Khaldun generally analyses social change, its indispensability, its course and its causes. At the last stage of analysing sedentary civilization, Ibn-Khaldun explained that human society is evolving in a cyclical manner through stages and that the sedentary stage is the end of human civilization. Though the end but not actually the end of the world because, the society will be revolving between the two typologies of Bedouin and Sedentary. He remarked: "It will later become clear that sedentary life constitutes the last stage of civilization and the point where it begins to decay" (Rosenthal, 1967, p.171). It is interesting to note that though Ibn Khalidun's explanations of change have been on ground for several centuries before the likes of Spengler, Tonybee wrote about it.

It is worthy to note that idea of cyclical theory of change could be explicitly found in the writings of Ibn Khaldun and it is much more alive and in line with the assumptions of several theorists of change in the twentieth century. Like Tonybee and Spengler, Ibn Khaldun's notion of change is cyclical in nature (The rise and Fall of Civilizations. Apart from its cyclical explanations, he also explained that each social system always sow the seed of its own destruction. His notion:

The Bedouins, accordingly mostly launch attacks against the sedentary people so as to cart away their property and gain access to the luxury lifestyle they live. Thus, there is transformation of a Bedouin Society into a sedentary society after conquest, in that regard, hitherto Bedouins would transform to sedentarists thereby experiencing what the earlier sedentarists experienced. On the long run, another Bedouins will also attack the former and transform into sedentary people and the cycles continue. For instance, once the barbarians solidify their control over the conquered society, they become attracted to its more refined aspects, such as literacy and arts, and either assimilate into or appropriate such cultural practices. Then, eventually, the former barbarians will be conquered by a new set of barbarians, who will repeat the process (Rosenthal, 1967, p. 173).

Ibn Khaldun sees the historical process as one of constant cyclical change, due mainly to the interaction of two groups - nomads and townspeople. It should thus be mentioned that, though, the cyclical theory gained prominence and wide attention and acceptance among modern scholars in the twentieth century and beyond, it is a line of reasoning that has been towed by Ibn-Khalidun centuries before then. According to Ogunbameru (2015, p. 29), "... the most frequently cited observation drawn from Ibn khaldun's work is the notion that when a society becomes a great civilisation, its high point is followed by a period of decay". In Ibn Khaldun's time and place, ruins left by many great and prosperous cities attested to the prior existence of high civilization. 


\section{Concluding Remarks}

As mentioned in the introductory aspect of the manuscript, the foregoing effort in this academic piece has been targeted at awakening 'a gigantic legend' and covering a gap in academic sociology by examining the sociological elements in Ibn-Khaldun's work. Such examination has brought to open the fact that sociology is a timeless endeavour that critical thinkers have always engage in for a long period of time. This effort has further shown that what many contemporary sociologists do has similar background with the thinking of many philosophers even before August Comte. The analysis in this paper has also show that, modern sociologists need to put some level of interest in the works of early philosophers as examining such works would go a long way in enriching our sociological knowledge in modern times, such knowledge would further assist the sociologists to improve on social livelihoods of people across the globe.

Inferring from the analysis in this presentation thus far, it could be observed that Ibn-Khaldun is a legend, an intellectual 'giant' in his own stand, a philosopher and essentially a sociologist that wrote extensively on different aspects of societal operations. Deducing from the analysis, it could be realized that Ibn-Khaldun contributed to various areas of sociology viz-a-viz: social organization, social relationship, economic sociology, political sociology, social change, ecological sociology, sociology of jurisprudence, social psychology, urban/rural sociology and so on. It is much more interesting that Ibn Khaldun's explanations of these broad areas of sociology has such intellectual depth and coverage such that they could compete favourably with the views of very notable sociologists that live after him. To this extent, based on the intellectual rich and qualitative sociological insights in Ibn-Khaldun's work, he is qualified to be referred to as sociologist in his own right and based on the relevance of his work to the discipline of sociology, sociologists in several universities globally should put vested interest in studying Ibn Khaldun as one of the fore runners of sociology and grandmaster of sociological thought. This would go a long way to bridge the gap of neglecting sociological timeless masterpiece and would also assist modern sociologists to use the 'evergreen' sociological theories to explain the dynamics of modern society and solve its complex social problems.

\section{References}

Brrom, L., \& Selznick, P. (1968). Sociology: A text with adapted studies. New York: McGraw-Hill.

Caksu, A. (2007). Ibn Khaldun and Hegel on Causality in History: Aristotelian Legacy Reconsidered. Asian Journal of Social Science, 35(1), 47-82.

Fischel, W. J. (1967). Ibn Khaldun in Egypt: His public functions and his historical research (13821406) A study in islamic historiography. Berkeley: University of California Press.

Ibn Khaldun, (1967). The Muqaddimah: An Introduction to History. Tr. Franz Rosenthal, Bollingen Series XLIII. Princeton University Press, Princeton,

Lawrence, D. (1984). Ibn Khaldun and islamic ideology. Leiden: E. J. Brill.

Mahdi, M. (1957). Ibn-Khaldun philosophy of history. London: George Allen and Unwin.

Mahdi, M. (1957). Ibn Khaldun's philosophy of History: A study in the philosophic foundation of the science of culture. London: George Allen \& Unwin.

Muhammad H. (nd.). Ibn Khaldun his life and work.

Ogunbameru, O.A (2015). Sociology: Origins, development and uses. Ibadan: Penthouse publication

Rabi, M.M. (1967). The political theory of Ibn Khaldun. Leiden: E.J Briell.

Ritzer, G. (2011). Sociological theory (Eight edition). New York: McGraw Hill.

Shankar-Rao, C.N. (2006). Sociology. New-Delhi: S. Chand and Company Limited. 